\title{
Review \\ Improving Cell Recovery: Freezing and Thawing Optimization of Induced Pluripotent Stem Cells
}

\author{
Markus Uhrig *, Fernando Ezquer (1) and Marcelo Ezquer * \\ Center for Regenerative Medicine, School of Medicine, Clínica Alemana-Universidad del Desarrollo, \\ Santiago 7610658, Chile; eezquer@udd.cl \\ * Correspondence: markus.uhrig@biomedicine-academia.de (M.U.); mezquer@udd.cl (M.E.)
}

Citation: Uhrig, M.; Ezquer, F.; Ezquer, M. Improving Cell Recovery: Freezing and Thawing Optimization of Induced Pluripotent Stem Cells. Cells 2022, 11, 799. https://doi.org/ $10.3390 /$ cells 11050799

Academic Editor: Andrea Pession

Received: 30 December 2021

Accepted: 16 February 2022

Published: 24 February 2022

Publisher's Note: MDPI stays neutral with regard to jurisdictional claims in published maps and institutional affiliations.

Copyright: (C) 2022 by the authors. Licensee MDPI, Basel, Switzerland. This article is an open access article distributed under the terms and conditions of the Creative Commons Attribution (CC BY) license (https:// creativecommons.org/licenses/by/ $4.0 /)$.

\begin{abstract}
Achieving good cell recovery after cryopreservation is an essential process when working with induced pluripotent stem cells (iPSC). Optimized freezing and thawing methods are required for good cell attachment and survival. In this review, we concentrate on these two aspects, freezing and thawing, but also discuss further factors influencing cell recovery such as cell storage and transport. Whenever a problem occurs during the thawing process of iPSC, it is initially not clear what it is caused by, because there are many factors involved that can contribute to insufficient cell recovery. Thawing problems can usually be solved more quickly when a certain order of steps to be taken is followed. Under optimized conditions, iPSC should be ready for further experiments approximately 4-7 days after thawing and seeding. However, if the freezing and thawing protocols are not optimized, this time can increase up to 2-3 weeks, complicating any further experiments. Here, we suggest optimization steps and troubleshooting options for the freezing, thawing, and seeding of iPSC on feeder-free, Matrigel ${ }^{\mathrm{TM}}$-coated, cell culture plates whenever iPSC cannot be recovered in sufficient quality. This review applies to two-dimensional (2D) monolayer cell culture and to iPSC, passaged, frozen, and thawed as cell aggregates (clumps). Furthermore, we discuss usually less well-described factors such as the cell growth phase before freezing and the prevention of osmotic shock during thawing.
\end{abstract}

Keywords: induced pluripotent stem cells; logarithmic cell growth phase; freezing protocol; thawing protocol; post-thaw cell recovery; iPSC storage and transport; preventing osmotic shock; cell aggregates; cell seeding density

\section{Introduction}

Induced pluripotent stem cells (iPSC), reprogrammed from somatic cells, offer unprecedented potential for regenerative medicine, drug screening, toxicology, and as cellular disease models [1,2]. Good protocols for cryopreservation and recovery after thawing with little loss in viability are prerequisites for their efficient use. In this review, we focus on the pitfalls common to many of the protocols currently available in the literature. We give an overview of the most important aspects that are important for a successful iPSC recovery such as cryopreservation, storage, transport, and thawing of iPSC, and we also discuss less well-described factors such as the logarithmic cell growth phase before freezing, clone-toclone variability, and the prevention of osmotic shock during thawing. To complement this information, the protocols for freezing and thawing that we have been using successfully in our laboratory in recent years are available upon request.

\section{Cryopreservation}

\subsection{General Guidelines for Working with iPSC during the Cryopreservation Process}

The absence of microbial contamination in the iPSC culture should be confirmed before freezing. Wearing face masks can prevent the transfer of Mycoplasma from the oral cavity (e.g., Mycoplasma orale) into the cryovials by respiration of the experimenter [3-5]. 
During cryopreservation, it is important to prevent the formation of ice crystals. Ice crystals have been shown to damage cell membranes [6]. Therefore, the tendency of water to form ice crystals must be reduced. Several cryoprotectant agents are used to prevent ice crystal formation such as dimethyl sulfoxide (DMSO), glycerol, propanediol, or methanol. The cryoprotectant agents must be able to cross the cell membrane and penetrate the cells without causing cytotoxicity [7]. Cryoprotectant agents are usually required to be hypertonic to get water out of the cells, which reduces the likelihood of intracellular ice crystal formation. For instance, a 10\% DMSO solution in cell culture medium has an osmolarity of approximately $1.4 \mathrm{osm} / \mathrm{L}$ [8]. Cells introduced into such a concentrated solution rapidly dehydrate because water leaves the cells to equilibrate the difference in osmotic pressure between the areas inside and outside of the cells. DMSO, in turn, permeates the cells to re-equilibrate. It was discovered that cells are primarily damaged by two factors: intracellular ice formation and cell dehydration [9-11]. It has since become clear that preventing these two factors from occurring and their delicate balance are essential for post-thaw cell recovery [12]. Hayashi et al. mentioned that on the one hand, the cooling rate should be slow to avoid intracellular ice crystal formation. On the other hand, the cooling rate should be fast to prevent cell dehydration. Both, intracellular ice formation and cell dehydration, should be balanced in order to assure best cell survival after thawing. Based on these considerations, they assumed three temperature zones for the slow freezing of human iPSC: 1. Dehydration zone, 2. Intracellular ice formation zone (nucleation zone), and 3. Further cooling zone [13]. They performed freeze/thaw experiments using iPSC to measure the cell survival rates at certain cooling rates. These experimental results were used to establish a statistical model for the cell survival rate. Then, this model was used to assess 16,206 three-zone temperature profiles. They determined an optimal three-zone profile and assumed that cell survival is best when an optimal cooling rate is applied for each of these zones [14]. Based on their model, they found that a constant cooling rate did not result in the best cell survival, but that rather a certain cooling rate at the right time during these three zones is the best. They suggested that for optimal cell survival during cryopreservation, it is the best to cool fast in the dehydration zone, followed by slow cooling in the nucleation zone, and again fast in the further cooling zone. This fast-slow-fast pattern is illustrated in Figure 6 in [14].

Human iPSC are more vulnerable to intracellular ice formation than many other human or animal cells [15]. Thus, it is important to strictly control the cooling rate for human iPSC. Ware and colleagues tested different controlled freezing rates for human embryonic stem cells (hESC) and found that a freezing rate within -0.3 and $-1.8{ }^{\circ} \mathrm{C} / \mathrm{min}$ is optimal for cell survival [16]. Li et al. observed a better post-thaw recovery of human iPSC when they were cooled at rates of -1 and $-3{ }^{\circ} \mathrm{C} / \mathrm{min}$ as compared to $-10^{\circ} \mathrm{C} / \mathrm{min}$. A rate of $-1^{\circ} \mathrm{C} / \mathrm{min}$ is a frequently used freezing rate for iPSC [17]. The best suitable cooling rate is cell type-specific [12]. Oocytes, for example, could be recovered well upon thawing when they were slowly cooled $\left(-0.3^{\circ} \mathrm{C} / \mathrm{min}\right)$ to $-30^{\circ} \mathrm{C}$, followed by a faster cooling $\left(-50{ }^{\circ} \mathrm{C} / \mathrm{min}\right)$ to $-150{ }^{\circ} \mathrm{C}$ before submerging them into liquid nitrogen [18]. Human oocytes are very susceptible to damage by ice crystals during freezing and thawing because of their large surface area/volume ratio and plasma membrane permeability [19]. Thus, particularly for oocytes, it is important to decrease the possibility of intracellular ice crystal formation [20].

Slow-freezing protocols (controlled-rate freezing) have been shown to result in good cell recovery after thawing [21]. During the freezing process, the cryovials are usually placed in cryocontainers, allowing for slow, controlled-rate freezing in $-80{ }^{\circ} \mathrm{C}$ freezers, and then transferred to liquid nitrogen tanks or $-150{ }^{\circ} \mathrm{C}$ freezers for long-term storage. Cells must not be put into liquid nitrogen directly without the controlled-rate freezing step at $-80^{\circ} \mathrm{C}$; by doing so, this missing step would harm the cells (an exception to this is the vitrification freezing method, described in Chapter 2.10).

Cryopreservation works best by maintaining cells below the intra- and extracellular glass transition temperatures and staff who wants to store cryopreserved iPSC properly, 
should ensure that the storage temperature does not rise above these two temperatures [22]. By doing so, all molecular processes cease, and damaging events, e.g., the harmful generation of free radicals, are prevented $[23,24]$. When thawing cells that had previously been stored at temperatures that were too warm, intracellular ice crystals may be assumed to have formed, possibly damaging the cells mechanically $[25,26]$. Especially at two temperatures, stressful events may occur that can harm the cells; one is the extracellular glass transition temperature at $-123^{\circ} \mathrm{C}$, the other is the intracellular glass transition temperature at $-47^{\circ} \mathrm{C}\left(-47^{\circ} \mathrm{C}\right.$ was reported for Jurkat $\mathrm{T}$ cells and may vary for other cell types [22]). The temperature of $-123^{\circ} \mathrm{C}$ is the extracellular glass transition temperature of DMSO at which the extracellular medium vitrifies. If the frozen cells reach a temperature warmer than $-123{ }^{\circ} \mathrm{C}$ or warmer than $-47^{\circ} \mathrm{C}$, the cells can become stressed, which may reduce viability upon thawing. Thus, cells should not become warmer than $-123{ }^{\circ} \mathrm{C}$ (or if this happens unintentionally, further warming to temperatures warmer than $-47^{\circ} \mathrm{C}$ should be prevented because this would inflict another stressful event onto the cells) [22]. Furthermore, Meneghel and colleagues observed particularly high cell mortality when the cells reached temperatures warmer than $-25{ }^{\circ} \mathrm{C}$ [22]. Warming frozen cells above the extracellular glass transition temperature of $-123^{\circ} \mathrm{C}$ can be prevented by storing iPSC, for example, in the vapor phase of liquid nitrogen or by storing the cells in $-150{ }^{\circ} \mathrm{C}$ freezers. The vapor phase in a cryotank has a temperature from approximately -150 to $-160{ }^{\circ} \mathrm{C}$, depending on various factors, but can also be warmer than $-150{ }^{\circ} \mathrm{C}$ or colder than $-160{ }^{\circ} \mathrm{C}$, depending on the distance from the level of the liquid nitrogen (Figure 1 in [27]). Depending on the level of liquid nitrogen and the design of the tank, the temperature of the vapor phase can vary, and the level should be monitored continuously so that enough liquid nitrogen remains in the tank (see Supplementary Information for more details). Yuan et al. demonstrated that the long-term storage of iPSC in $-80^{\circ} \mathrm{C}$ freezers is possible for at least one year without compromising cell viability and pluripotency upon thawing by adding Ficoll 70 to the freezing solution [28].

\subsection{Effect of Passaging Cells as Aggregates or as Single Cells on Cell Recovery after Thawing}

There are mainly two ways of passaging and freezing iPSC: (A) as cell aggregates (clumps) [29] or (B) as single cells [30]. Both ways have advantages and disadvantages. (A) For aggregates, the following advantages/disadvantages are reported in the literature: (1) cell-cell contacts with neighboring cells support cell survival, (2) freezing/thawing of aggregates usually results in a faster recovery compared to single cells because single cells need more time to transition back to form aggregates, (3) the variability in aggregate size leads to a difference in the penetration of the cryoprotectant into the core of the aggregates during the freezing process, which in turn may impact cell viability after thawing. (B) For single cells, the following advantages/disadvantages are described in the literature: (1) better quality control of single cells because cells can be better quantified, resulting in a more consistent recovery time from vial to vial (due to accurate cell counting and viability measurements), (2) single iPSC often need the Rho-associated protein kinase inhibitor (ROCK inhibitor) for survival [31,32]. In this review, we refer to cryopreservation and cell recovery as cell aggregates.

\subsection{Optimization of Protocol Steps during Cryopreservation}

Immediately before freezing iPSC, it is critical to optimize the conditions to achieve successful cell recovery. iPSC clones with a very high proportion of differentiated cells should be discarded because the differentiated cells are an undesirable component of the culture and may induce the differentiation of the (so far undifferentiated) iPSC within colonies. If an acceptable number of spontaneously differentiated cells are present in the iPSC culture, these cells should be removed manually under the microscope before freezing, or by short incubation times with an EDTA-based or another suitable dissociation reagent [33]. The iPSC should be harvested during the logarithmic growth phase (log phase, synonym: exponential phase) before the cells enter the stationary phase and should 
be frozen subsequently (Table 1); this is described in more detail in the Supplementary Information. iPSC that are frozen during the stationary phase are usually difficult to recover upon thawing [34-36].

Table 1. Optimization of protocol steps during freezing.

\begin{tabular}{|c|c|c|c|c|}
\hline Factors & Not Optimized & Optimized & Critical Steps & References \\
\hline Cell growth phase & $\begin{array}{l}\text { Cells have already } \\
\text { entered the stationary } \\
\text { phase. }\end{array}$ & $\begin{array}{l}\text { Freeze cells during the } \\
\text { log growth phase, } \\
\text { approx. } 2-4 \text { days after } \\
\text { passaging. }\end{array}$ & $\begin{array}{l}\text { With the goal of reaching a } \\
\text { sufficiently high cell number (high } \\
\text { confluency), it may happen that the } \\
\text { cells are unintentionally grown for } \\
\text { too many days and thus have } \\
\text { already entered the stationary phase. }\end{array}$ & [34-36] \\
\hline Cell number & Cell number too low. & $\begin{array}{l}\text { Let cells grow up to } \\
\text { approx. } 70-80 \% \\
\text { confluency. } \\
\text { Freeze iPSC from one } \\
\text { well of a six-well plate } \\
\text { in one ml of freezing } \\
\text { solution (one cryovial). }\end{array}$ & $\begin{array}{l}\text { While the iPSC number is growing, } \\
\text { make sure that the cells are still } \\
\text { within the log growth phase upon } \\
\text { freezing. If necessary, whenever cells } \\
\text { have already entered the stationary } \\
\text { phase, split 1:2-1:4 and freeze } \\
2-4 \text { days later. }\end{array}$ & {$[36,37]$} \\
\hline Cell aggregate size & $\begin{array}{l}\text { Cell aggregates are } \\
\text { disrupted, resulting in } \\
\text { single cells or cell } \\
\text { aggregates that are too } \\
\text { small. }\end{array}$ & $\begin{array}{l}\text { Avoid harsh pipetting. } \\
\text { Frequently, a cell } \\
\text { aggregate size of } \\
50-200 \mu \mathrm{m} \text { is } \\
\text { recommended. }\end{array}$ & $\begin{array}{l}\text { From harvesting until the final steps } \\
\text { of freezing, the cell aggregates can be } \\
\text { disrupted in many of these steps. } \\
\text { Therefore, all steps should be carried } \\
\text { out gently *. }\end{array}$ & $\begin{array}{l}\text { [37], STEMCELL } \\
\text { Technologies website }\end{array}$ \\
\hline $\begin{array}{l}\text { Differentiated cells in } \\
\text { the iPSC culture }\end{array}$ & $\begin{array}{l}\text { Too many } \\
\text { spontaneously } \\
\text { differentiated cells } \\
\text { appear near or } \\
\text { within the iPSC colonies. }\end{array}$ & $\begin{array}{l}\text { Remove differentiated } \\
\text { cells manually under the } \\
\text { microscope or by short } \\
\text { incubation times with } \\
\text { an EDTA-based } \\
\text { dissociation reagent on a } \\
\text { regular basis and } \\
\text { directly before freezing. }\end{array}$ & $\begin{array}{l}\text { The number of differentiated cells } \\
\text { can vary from clone to clone. iPSC } \\
\text { clones which very rapidly } \\
\text { differentiate spontaneously should } \\
\text { be discarded. Those with an } \\
\text { acceptable (low) number of } \\
\text { differentiated cells should be } \\
\text { manually cleaned on a regular basis } \\
\text { (differentiated cells should be } \\
\text { removed under a microscope before } \\
\text { freezing). Some lots of FBS (e.g., not } \\
\text { ESC-qualified FBS) possibly induce } \\
\text { differentiation; thus, it may be } \\
\text { considered to withdraw FBS after } \\
\text { thawing (provided that the freezing } \\
\text { solution contained FBS). }\end{array}$ & {$[33,38-40]$} \\
\hline
\end{tabular}

* e.g., by using a gentle dissociation solution for passaging, a gentle handling of the cells, and short centrifugation times (e.g., $2.5 \mathrm{~min}$ ) at relatively low centrifugal forces (e.g., $200 \mathrm{~g}$ ).

\subsection{Logarithmic Cell Growth Phase before Freezing}

It has been shown that iPSC recover best after thawing, when they are frozen during the log growth phase [36]. In this phase, cells divide rapidly, which favors a good recovery. For iPSC, it is often not very well-described in the literature when exactly the log phase starts and ends. The best option would be to experimentally determine the beginning and the end of the log phase by measuring cell numbers and generating growth curves. With the goal of reaching high cell numbers (high cell density) before freezing, some experimenters may unintentionally tend to grow the cells beyond the log growth phase and to freeze them subsequently (when the cells have already entered the stationary phase). This, however, leads to poor cell survival after thawing [41]. A straightforward way to reverse this, if the cells are already in the stationary phase, would be to split the cells 1:2-1:4, then let the cells regrow for approximately 2-4 days, and then to freeze them. This strategy takes the cells once again into the log growth phase. After evaluating the current literature, freezing iPSC approximately 2-4 days after passaging proved to be the best means of achieving a successful and fast recovery after thawing $[35,36]$. Liu and Chen saw the best cell recovery after thawing when iPSC were frozen 2-3 days after passaging. In contrast, they saw poor 
survival when cells were frozen 5-6 days after passaging [36]. Freezing the cells one day after passaging them, has the disadvantage of the cells possibly still being in the lag phase (not yet in the log growth phase) [35] and that the cell number is still quite small because the cells do not have much time to proliferate within one day. Therefore, we routinely freeze our iPSC $2-4$ days after passaging and see good recovery after thawing. It must also be considered that the very first passages of iPSC directly after picking the colonies during reprogramming (approximately passages 1-3, early-passage cells), usually have lower survival rates after cryopreservation, thawing, and plating than those frozen at later passages. Therefore, in our laboratory, we usually add ROCK inhibitor to the cell culture medium when thawing early-passage cells to increase cell survival [42].

\subsection{Serum-Free Cryopreservation of iPSC}

For clinical applications, fetal bovine serum (FBS) cannot be used as a cryopreservation supplement for iPSC due to its risk of disease transmission and possible xenogeneic immune reactions in the transplanted host. Instead, knockout serum replacement (KSR) can be used to replace serum, or serum can be omitted completely without substituting it with KSR [43]. In many laboratories, the freezing medium CryoStor ${ }^{\circledR}$ CS10 (STEMCELL Technologies, Vancouver, BC, Canada) is used. This is a serum-free, animal componentfree, defined, and cGMP-manufactured cryopreservation medium containing $10 \% \mathrm{DMSO}$. Other serum-free and frequently used freezing media are the CELLBANKER ${ }^{\circledR} 2$ (Zenogen Pharma, AMSBIO, Cambridge, MA, USA) [44] and STEM-CELLBANKER ${ }^{\circledR}$-GMP grade (Zenogen Pharma, AMSBIO) [45,46]. Liu and Chen dissociated their iPSC with EDTA/PBS (ethylenediaminetetraacetic acid/phosphate-buffered saline) before cryopreservation, and instead of using serum, they froze the cells in 90\% Essential $8^{\mathrm{TM}}$ (E8) plus 10\% DMSO and did not observe any recovery problems by not adding serum [36]. In our own laboratory, we do not add serum either and have not experienced any problems in cell recovery after thawing as long as other factors were optimized; for example, by ensuring that the cells are in the logarithmic growth phase before freezing, by not disrupting cell aggregates too much during freezing and thawing, and by maintaining a high cell seeding density and adding ROCK inhibitor during thawing [32]. As freezing medium, we use $90 \%$ StemFlex $^{\mathrm{TM}}$ medium (Thermo Fisher Scientific, Waltham, MA, USA) or 90\% mTeSR1 ${ }^{\mathrm{TM}}$ (STEMCELL Technologies) plus 10\% DMSO without adding FBS or KSR. However, it has been described that adding 30\% KSR to the freezing medium can improve cell recovery after thawing. The Allen Institute for Cell Science, USA, recommends a freezing medium consisting of $60 \% \mathrm{mTeSR} 1 \mathrm{TM}, 30 \% \mathrm{KSR}$ and $10 \% \mathrm{DMSO}$ ) in one of their protocols. A full cryopreservation protocol is available on the website of the Allen Institute for Cell Science: www.allencell.org/ uploads/8/1/9/9/81996008/aics_banking_guidelines_external_v1.3_200211.pdf (accessed on 15 February 2022). Adding 30\% KSR supports cell recovery because in their protocol, they dissociate the iPSC with Accutase ${ }^{\mathrm{TM}}$ before freezing, which makes the iPSC more vulnerable. The Stem Cell Biobank of the Coriell Institute for Medical Research, USA, recommends a freezing medium consisting of $90 \% \mathrm{KSR}$ and $10 \%$ DMSO (www.coriell.org/ 0/pdf/NINDS/ipsc/ND41866_Protocol.pdf) (accessed on 15 February 2022). in one of their protocols. Wagner and Welch used two different freezing media-freezing medium A ( $50 \%$ of final volume): $50 \%$ DMEM/F12, $50 \%$ KSR, and freezing medium B (50\% of final volume): $80 \%$ DMEM/F12, $20 \%$ DMSO. Both media were added to the cells at different times, resulting in a final composition of their cryopreservation medium that was 65\% DMEM/F12, 25\% KSR, and 10\% DMSO [47,48].

\subsection{Cryopreservation with Serum}

A large variability (10-80\%) in the ability of iPSC and ESC to attach to coated cell culture plates after thawing has been reported in several laboratories [49,50]. Ha et al. concluded in their publication that adding 5\% DMSO + 50\% FBS + 10\% ethylene glycol to the medium was an optimal cryoprotectant for their slow freezing/rapid thawing protocol of human embryonic stem cells [51]. Fernandes and colleagues could significantly 
improve cell recovery upon thawing when they added the antioxidant catalase to their FBS containing freezing medium [52]. Some FBS lots (e.g., FBS that is not ESC-qualified) contain growth/differentiation factors which can induce differentiation of iPSC and ESC (e.g., if grown as embryoid bodies) $[39,40,53]$ For this reason, regarding iPSC frozen in a serum-containing freezing solution, it should be considered to remove the serum upon thawing to reduce the risk of unwanted differentiation of the iPSC.

\subsection{DMSO Concentration in the Freezing Medium}

Liu and Chen found that 10-12.5\% DMSO in E8 medium provides the best cryopreservation efficiency (Figure 5B in [36]). Furthermore, they found two important facts: 1. EDTA dissociation allowed good survival of human pluripotent stem cells in both passaging and cryopreservation; 2 . DMEM/F12 with $10 \%$ DMSO was sufficient for cryopreservation when cells were dissociated with EDTA. This is in line with our own observation using $10 \%$ DMSO in StemFlex ${ }^{\mathrm{TM}}$ medium (Thermo Fisher Scientific) or in mTeSR1 ${ }^{\mathrm{TM}}$ (STEMCELL Technologies), where we see good cryopreservation efficiency. For cells preserved in a freezing medium containing DMSO, it is generally recommended to wash out or dilute the DMSO immediately post-thaw because DMSO harms the cells at higher concentrations [54].

\subsection{Different Dissociation Solutions Have a Strong Impact on Cryopreservation and Cell Recovery after Thawing}

Membrane adhesion proteins use bivalent ions $\left(2^{+}\right.$charged ions), such as calcium- and magnesium ions, to form cell-cell and cell-substrate connections. The membrane adhesion proteins on the cells bind to the $2^{+}$charged ions, which act as a link (bridge) between neighboring cells and the substrate (e.g., Matrige ${ }^{\mathrm{TM}}$ coating on plastic dishes). Negatively charged amino acids of the membrane adhesion proteins on the cells bind the $2^{+}$charged ions, thus promoting cell adhesion. EDTA is known to be a good chelator of bivalent cations. Thus, EDTA chelates, e.g., calcium- and magnesium ions so that these bivalent ions are no longer available to build the bridge between the cells and the coating on the cell culture dish or between each other.This in turn facilitates cell dissociation. This is reinforced by using a $\mathrm{Mg}^{2+}$ - and $\mathrm{Ca}^{2+}$-free PBS that can be used to wash out $\mathrm{Mg}^{2+}$ - and $\mathrm{Ca}^{2+}$ directly before applying EDTA. Especially for passaging iPSC before cryopreservation, the composition of the dissociation reagent is very important. Beers and colleagues demonstrated that certain combinations of dissociation reagents, cell seeding densities, and the presence or absence of ROCK inhibitor have a strong impact on cell recovery after passaging (Figure 1a in [37]). This also applies to passaging, subsequent cryopreservation, and thawing. They demonstrated that a combination of trypsin or Accutase ${ }^{\mathrm{TM}}$ (both enzymatic), together with a low cell seeding density and without ROCK inhibitor strongly reduces the survival of iPSC [37]. Other combinations are less problematic: Versene ${ }^{\mathrm{TM}}\left(\mathrm{Gibco}^{\circledR}\right.$, Waltham, MA, USA), for example, is a gentle non-enzymatic cell dissociation reagent that contains PBS and EDTA. Since it contains no enzymes, it is gentler to the cells; thus, cells can usually be recovered well if combined with a high cell seeding density. Trypsin, in contrast, is more aggressive because it digests the lysine and arginine residues of the carboxy termini of proteins. It digests adhesive cytoskeleton proteins of the cells that anchor the cells to the extracellular matrix. It breaks down cell-to-cell adhesions and cell-to-culture vessel adhesions. In contrast to EDTA, which does not release cell-surface components, trypsin releases large amounts of cell-surface glycoproteins and glycosaminoglycans [55]. Accutase $^{\mathrm{TM}}$, which is commercially available, mimics the action of trypsin and collagenase. Accutase $^{\mathrm{TM}}$ is a mixture of enzymes with proteolytic, collagenolytic, and DNase activity. It is claimed to be gentler than trypsin; however, in combination with a low cell seeding density and without ROCK inhibitor, problems may occur regarding the recovery of pluripotent cells [37,56-58].

A suitable dissociation solution should be selected carefully because these solutions have a strong impact on cryopreservation and cell recovery after thawing. Non-enzymatic dissociation solutions: The treatment of cell aggregates with (1) non-enzymatic EDTA/PBS 
produces relatively small cell aggregates during passaging and results in a high survival rate after thawing. Liu and colleagues demonstrated that EDTA-dissociated cells survive better after cryopreservation than cells treated with dispase [36]. (2) To reduce stress for the iPSC and thus increase cell recovery, we opted to use a gentle way of passaging the cells. For this reason, in our laboratory, we use the enzyme-free Gentle Cell Dissociation Solution (STEMCELL Technologies, Catalog \#07174) in combination with Cell Lifters (STEMCELL Technologies, Catalog \#38067), resulting in relatively large cell aggregates during passaging and cryopreservation; consequently, we see good cell recovery after thawing. This is in line with other laboratories which also use the same means for passaging their iPSC [59]. Enzymatic dissociation solutions: (1) Dispase, collagenase, TrypLE ${ }^{\mathrm{TM}}$, Trypsin, and Accutase ${ }^{\mathrm{TM}}$. While treatment with dispase and collagenase results in cell clumps (depending on the incubation time), treatment with Accutase ${ }^{\mathrm{TM}}$, TrypLE ${ }^{\mathrm{TM}}$, and trypsin results in dissociation into single cells $[30,60]$. For all enzymatic treatments leading to single iPSC, adding ROCK inhibitor to the medium upon thawing is highly recommended for better cell survival. Beers and colleagues tested different non-enzymatic and enzymatic dissociation solutions for cell passaging and presented a well-illustrated and comprehensible figure in their publication (Figure 1a in [37]). They stressed the importance of maintaining a high cell seeding density for better cell survival, especially in combination with some of their tested dissociation solutions, and observed good cell survival after passaging, e.g., with EDTA [37]. To reduce stress for the iPSC and thus increase cell survival, in our own laboratory, we sometimes use Versene $^{\mathrm{TM}}$ (Gibco, catalog number 15040066), a non-enzymatic EDTA-containing solution for passaging. For the freezing of our iPSC after passaging with Versene ${ }^{\mathrm{TM}}$, we can confirm good cell recovery after thawing which is also reported by Hedges et al. [61]. In our hands, the dissociation of iPSC with EDTA and the subsequent freezing results in smaller cell aggregates upon thawing and plating than by using the Gentle Cell Dissociation Solution in combination with Cell Lifters. In our laboratory, using Versene ${ }^{\mathrm{TM}}$ or the Gentle Dissociation Solution ${ }^{\mathrm{TM}}$ together with Cell Lifters ${ }^{\mathrm{TM}}$ for passaging and the subsequent freezing both result in good cell recovery after thawing.

\subsection{Economic View on Media, Reagents, and Supplements for the Cryopreservation of iPSC}

Working with iPSC can be expensive, but there are ways to reduce costs. The media, supplements, growth factors, and the iPSC themselves are among the most important cost factors. Here, we specifically focus on those factors associated with cryopreservation. High costs are especially caused by using commercially available, integration-free, feeder-free, and xeno-free components. Beers and colleagues established a cost-effective and efficient reprogramming platform, including an optimization of their freezing efficiencies [62]. They worked with a 24-96 well format, which saved costs as compared to the often used six-well format, because a smaller volume of iPSC culture medium was necessary. Instead of expensive commercial dissociation reagents, they used EDTA in PBS. They efficiently cryopreserved iPSC directly on 48-well plates (on-plate cryopreservation of iPSC colonies). They preferred the use of Essential 8 medium (E8, Thermo Fisher Scientific, Gibco \#A1517001) over other more expensive media for iPSC. E8 is a xeno-free medium especially formulated for the growth and expansion of human pluripotent stem cells (PSC). E8 was originally developed in the laboratory of stem cell research pioneer James Thomson (University of Wisconsin-Madison). He and his colleagues made their formulation of E8 public so that E8 can be produced by other laboratories, which may reduce costs compared to buying commercially available E8 (Methods section in [49]). The composition of E8 is: DMEM/F12, L-ascorbic acid-2-phosphate magnesium $(64 \mathrm{mg} / \mathrm{L})$, sodium selenium $(14 \mu \mathrm{g} / \mathrm{L}), \mathrm{FGF} 2(100 \mu \mathrm{g} / \mathrm{L})$, insulin $(19.4 \mathrm{mg} / \mathrm{L}), \mathrm{NaHCO}_{3}(543 \mathrm{mg} / \mathrm{L})$, and transferrin (10.7 mg/L), TGF $\beta 1(2 \mu \mathrm{g} / \mathrm{L})$, or NODAL (100 $\mu \mathrm{g} / \mathrm{L})$ [49]. Furthermore, the formulation of mTeSR1 (STEMCELL Technologies, Catalog \#38067) is publicly available and can thus be produced by other laboratories at reduced costs (see [63] and Supplementary Table 1 in [64]). For many experiments, such as in vitro experiments, it is not always necessary to use expensive commercial freezing media. Instead, $90 \%$ E8 or mTeSR1 medium plus 
$10 \%$ DMSO can be used as a freezing medium provided that other factors are optimized (log growth phase before freezing, using a gentle dissociation reagent such as EDTA for passaging before freezing, etc.). Some laboratories use $90 \%$ FBS plus $10 \%$ DMSO as a freezing medium for iPSC [65]. A cheaper option would be to reduce the proportion of FBS (e.g., from $90 \%$ to $50 \%$ ) or to use less KSR (e.g., $25 \%$ instead of $90 \%$ ) as an alternative to FBS, which have both been shown to result in good cell recovery upon thawing $[47,48,51]$.

\subsection{Vitrification}

Vitrification (from Latin: vitrum, glass) describes the transformation of a substance into a glass-like, non-crystalline, amorphous solid. Vitrification in cryopreservation is a method used to avoid the forming of ice crystals that could harm the cells [66]. During the vitrification process, the forming of ice crystals is prevented by ultra-fast freezing and dehydration of the cells [67]. For vitrification, cells resuspended in a freezing solution in suitable straws or capillaries can be vitrified by submerging them directly in liquid nitrogen $\left(-196^{\circ} \mathrm{C}\right)$ without an intermediary, slow-freezing step in freezing containers. This vitrification procedure transforms the cells, together with the freezing solution, into a non-crystalline glassy phase $[68,69]$. The following four factors are especially important for cell survival during the vitrification and thawing process: The sample volume, cooling rate, warming rate, and the viscosity $[70,71]$. The cells are usually resuspended in a very small volume of a freezing solution containing relatively high concentrations of cryoprotectant(s). To avoid the cytotoxic effects of the cryoprotectant, this contact of the cells with the cryoprotectant is kept rather short, directly followed by rapid cooling in liquid nitrogen. The high osmolarity of the freezing solution quickly leads to a dehydration of the cells, and submerging them into liquid nitrogen $\left(-196^{\circ} \mathrm{C}\right)$ rapidly vitrifies the freezing solution together with the cells so that the remaining intracellular water does not have time to form damaging ice crystals. During this process, the cells undergo a transition from $20{ }^{\circ} \mathrm{C}$ room temperature to $-196^{\circ} \mathrm{C}$ in less than two seconds, resulting in very fast cooling rates of $-10,000{ }^{\circ} \mathrm{C} /$ minute or faster $[70,71]$.

During a successful vitrification process, ice formation is completely prevented. However, for many vitrification protocols, a high concentration of cryoprotectants is needed, and this is usually toxic for sensitive cells such as stem cells and oocytes [18,21,72-75]. The higher the cooling rate, the lower the cryoprotectant concentration needed for vitrification, and thus the lower the cytotoxicity [76]. Xiaoming He and colleagues developed a quartz microcapillary system to reach ultra-fast cooling rates that lead to vitrification, while using a low, non-toxic concentration of cryoprotectants (2 M intracellular 1,2-propanediol and $0.5 \mathrm{M}$ extracellular trehalose) [77]. Using their quartz microcapillary with an outer diameter of $0.2 \mathrm{~mm}$ and a wall thickness of $0.01 \mathrm{~mm}$, they could achieve ultra-fast cooling rates (faster than $-100,000{ }^{\circ} \mathrm{C} / \mathrm{min}$ ) that allowed for the use of non-toxic concentrations of cryoprotectants. The very thin wall and diameter of the quartz capillary allowed for such high cooling rates and thus low and non-toxic levels of the cryoprotectants. The boundary heat transfer coefficient, the inner diameter of the quartz microcapillary, and the thermal diffusivity of different materials had a significant effect on the cooling rate (Figure 4 in [77]). Using this vitrification protocol, He et al. reached a survival rate of more than $70 \%$ for mouse ESC. These ESC attached well, proliferated normally, and retained the undifferentiated properties of pluripotent cells [77]. Several vitrification methods have been developed for iPSC. High cell survival rates after thawing could be achieved by adherent vitrification or by the CryoLogic vitrification method (CVM) [78,79] In mouse oocytes, it was shown that a rapid warming rate is essential for cell survival. Researchers have concluded that warming rates that are too slow leave time for the forming of small intracellular ice by recrystallization, eventually destroying the cells. If oocyte samples, vitrified in an ethylene glycol-acetamide-Ficoll-sucrose solution, were warmed at a rate of $2950^{\circ} \mathrm{C} / \mathrm{min}$, the cell survival rate would be $>80 \%$, whereas for those warmed at $139^{\circ} \mathrm{C} / \mathrm{min}$, the survival rate would be near $0 \%$ [70]. Apart from the positive aspects of the vitrification method, it has to be mentioned that it also comes along with some disadvantages, such as the fact that very 
small sample volumes and higher cryoprotectant concentrations are necessary, which could lead to cell death if a proper thawing process is not applied [20]. Furthermore, a longer duration of the exposure to these cryoprotectants can be detrimental [80,81], as well as certain temperatures during cooling and warming [82,83]. Gallardo and colleagues stated that despite the ultra-fast cooling and warming rates of vitrification, the procedure as a whole is time-consuming. However, they could shorten the duration of their vitrification protocol by a two-minute exposure to increasingly hypertonic standard cryoprotectant solutions [20].

\section{Thawing of iPSC}

The fast thawing of cryovials containing iPSC is recommended. Slow thawing with slow warming rates can possibly damage the cells by recrystallization or by the prolonged exposure of the cells to high extracellular concentrations of cryoprotectants [84]. For fast thawing, iPSC are typically thawed in a $37^{\circ} \mathrm{C}$ water bath, or for clinical-grade iPSC, in a thermoblock or warm bead bath (to reduce contamination risks). After taking the cryovial out of the liquid nitrogen tank, it is recommendable to transport the cells to the water bath in an ice block container in order to prevent a prolonged thawing time, which could reduce viability [67]. Holding the frozen cryovial in the water bath for approximately two minutes is usually sufficient to fast-thaw the cells. Especially if the quality of the frozen iPSC is unknown, it is recommended to add ROCK inhibitor (e.g., Y-27632) to the cell culture medium upon thawing (see Table 2, and described in more detail in the Supplementary

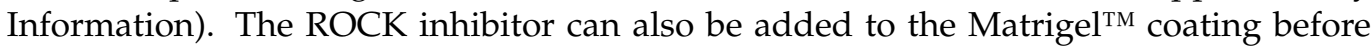
its polymerization, which has been shown to improve cell attachment after thawing and plating [85]. Pakzad et al. could increase the plating efficiency of human iPSC and human ESC by adding ROCK inhibitor Y-27632 to the Matrigel ${ }^{\mathrm{TM}}$. They ruled out possible nonspecific effects by adding another ROCK inhibitor (HA-1077/Fasudil, ROCK 2 inhibitor) to the Matrigel ${ }^{\mathrm{TM}}$ and also observed a better plating efficiency for this ROCK 2 inhibitor [86].

Table 2. Optimization of protocol steps during thawing and plating.

\begin{tabular}{|c|c|c|c|c|}
\hline Factors & Not Optimized & Optimized & Critical Steps & References \\
\hline Coating & $\begin{array}{l}\text { Wrong or expired coating } \\
\text { substance. }\end{array}$ & $\begin{array}{l}\text { Use good quality } \\
\text { Matrigel }{ }^{\mathrm{TM}} \text { or another } \\
\text { suitable coating substance. }\end{array}$ & $\begin{array}{l}\text { Thaw and aliquot } \\
\text { Matrigel }{ }^{\mathrm{TM}} \text { according to } \\
\text { SOP on ice }{ }^{*} \text {. }\end{array}$ & $\begin{array}{l}\text { [87], Corning and BD } \\
\text { Biosciences websites. }\end{array}$ \\
\hline Cell number for seeding & $\begin{array}{l}\text { Cell number too low, } \\
\text { resulting in loss of cell-cell } \\
\text { contacts. }\end{array}$ & $\begin{array}{l}\text { Assure high cell density } \\
\text { upon seeding. }\end{array}$ & $\begin{array}{l}\text { Try to reach a high cell } \\
\text { density **. If necessary, by } \\
\text { seeding the given number } \\
\text { of cells (e.g., thawed cells } \\
\text { from one cryovial) onto a } \\
\text { smaller surface (smaller } \\
\text { well). }\end{array}$ & {$[37,88]$} \\
\hline ROCK inhibitor & $\begin{array}{l}\text { ROCK inhibitor is missing } \\
\text { in the medium. }\end{array}$ & $\begin{array}{l}\text { Add } 10 \mu \mathrm{M} \text { ROCK } \\
\text { inhibitor. }\end{array}$ & $\begin{array}{l}\text { ROCK inhibitor is helpful } \\
\text { for cell attachment and } \\
\text { survival, especially if } \\
\text { other factors are not } \\
\text { optimized (e.g., disrupted } \\
\text { cell aggregates, low cell } \\
\text { seeding density). If cells } \\
\text { are completely } \\
\text { singularized, adding } \\
\text { ROCK inhibitor is very } \\
\text { important for cell survival. }\end{array}$ & {$[31,32,37,42,89,90]$} \\
\hline
\end{tabular}


Table 2. Cont.

\begin{tabular}{|c|c|c|c|c|}
\hline Factors & Not Optimized & Optimized & Critical Steps & References \\
\hline Cell aggregate size & $\begin{array}{l}\text { Cell aggregates are } \\
\text { disrupted, resulting in } \\
\text { single cells or cell } \\
\text { aggregates that are too } \\
\text { small. }\end{array}$ & $\begin{array}{l}\text { Avoid harsh pipetting. } \\
\text { Use ROCK inhibitor, } \\
\text { especially if aggregates are } \\
\text { significantly smaller than } \\
\text { approx. } 50 \mu \mathrm{m} \text {. }\end{array}$ & $\begin{array}{l}\text { During the whole thawing } \\
\text { and seeding process, the } \\
\text { cell aggregates can be } \\
\text { disrupted. Therefore, all } \\
\text { steps should be carried } \\
\text { out gently. }\end{array}$ & $\begin{array}{l}\text { [37], STEMCELL } \\
\text { Technologies website }\end{array}$ \\
\hline Osmotic shock & $\begin{array}{l}\text { The medium is first } \\
\text { poured into a } 15 \mathrm{~mL} \\
\text { conical tube, then all the } \\
\text { thawed cells from the } \\
\text { cryovial are added } \\
\text { suddenly and at once to } \\
\text { the medium in the tube. }\end{array}$ & $\begin{array}{l}\text { Put the thawed cells in a } \\
15 \mathrm{~mL} \text { conical tube first, } \\
\text { then add medium slowly } \\
\text { in a dropwise manner. }\end{array}$ & $\begin{array}{l}\text { A sudden change in the } \\
\text { osmolarity of the freezing } \\
\text { solution around the cells } \\
\text { may cause a rapid stream } \\
\text { of water across the } \\
\text { membranes of the cells. } \\
\text { This may stress the cells, } \\
\text { making them more prone } \\
\text { to die. Avoiding this kind } \\
\text { of stress can contribute to } \\
\text { better cell survival. }\end{array}$ & $\begin{array}{l}\text { [91,92], European Bank for } \\
\text { induced pluripotent stem } \\
\text { cells (EBiSC) }\end{array}$ \\
\hline
\end{tabular}

${ }^{*}$ Briefly, thaw Matrigel ${ }^{\mathrm{TM}}$ on ice in a refrigerator at $4^{\circ} \mathrm{C}$. Prepare aliquots on ice using pre-chilled tubes and store them at $-20^{\circ} \mathrm{C}$ or $-80^{\circ} \mathrm{C}$. Take Matrige ${ }^{\mathrm{TM}}$ aliquot(s) from the freezer and prepare the coating solution on ice with $4{ }^{\circ} \mathrm{C}$ cold medium (DMEM/F12; Matrigel ${ }^{\mathrm{TM}}$ will start to form a gel above $10^{\circ} \mathrm{C}$ ). Pour the coating solution into cell culture dishes and let it gel at room temperature or at $37^{\circ} \mathrm{C}$ in an incubator for approximately one hour. ${ }^{* *}$ A low cell density, and consequently a loss of cell-cell contacts, is particularly critical if iPSC are singularized and no ROCK inhibitor is added. *** Gentle handling of cells, short centrifugation time (e.g., 2.5 min) at low relative centrifugal forces (e.g., $200 \mathrm{~g})$.

\subsection{Plasticware}

In our laboratory, we usually coat conventional plastic cell culture dishes (Corning, Falcon, catalog number 353046, 6-well, polystyrene) with Matrigel ${ }^{\mathrm{TM}}$ and see good attachment for our iPSC. The Wellcome Sanger Institute also uses these dishes to cultivate their iPSC [93]. Sometimes, we use dishes with a Nunclon ${ }^{\mathrm{TM}}$ Delta surface treatment (Thermo Fisher Scientific, Nunc, catalog number 140675, 6-well, treated polystyrene). Nunclon ${ }^{\mathrm{TM}}$ Delta is a surface modificationthat makes the polystyrene surface of the culture vessel more hydrophilic. Using the same Matrige ${ }^{\mathrm{TM}}$ coating for these dishes that we also use for the normal plastic dishes, we see a slightly better cell attachment (approximately 10-15\% more cells attach to the Nunclon ${ }^{\mathrm{TM}}$ Delta surface-treated dishes). These Nunclon ${ }^{\mathrm{TM}}$ Delta surfacetreated dishes are also used by other laboratories for cultivating iPSC [36,94]. The slightly better attachment may be caused by the hydrophilic surface and/or by the high surface roughness. Nunclon ${ }^{\mathrm{TM}}$ Delta had the largest root mean squared (RMS) roughness of about $6 \mathrm{~nm}$ compared to the other surface modifications tested; see Figure 2c in [95].

\subsection{Cell Attachment, Counting, and Viability}

Cell attachment and proliferation after thawing are commonly used to evaluate viability. Quantifying post-thaw cell viability is important and may, for example, be performed by using a trypan blue exclusion assay or other methods [96]. While the trypan blue exclusion assay only results in a very rough, unprecise estimation of the number of living and dead cells, there are better options, for example, using an automated cell counting instrument such as the CASY ${ }^{\circledR}$ Cell Counter \& Analyzer (OLS OMNI Life Science, Bremen, Germany) $[97,98]$. This is a highly accurate and precise analyzer for cell lines, primary cells, and all stem cell types, including iPSC and ESC [98-100]. The CASY ${ }^{\circledR}$ counter can measure the total cell number. It can also measure the number of viable and dead cells of all possible cell types. No interference with dyes can occur because they are not required for the measurements. Another remarkable feature is its ability to measure cell sizes, their size distribution, cell aggregation, and cell debris $[99,101]$. Single and aggregated pluripotent stem cells can be measured, making it the ideal device for personalized and regenerative medicine [102]. Reproducible results are displayed in a single graph, taking less than one minute per measurement, with no counting chambers or slides needed. It is GMP/GLP 
compliant, easy to use, and no sample preparation is necessary. Further recommendable devices that can be used to count cells accurately and precisely are flow cytometers such as the NovoCyte instruments (Agilent, Santa Clara, CA, USA). These are benchtop flow cytometers, with up to five lasers and complex cell analysis capabilities. With an intuitive and straightforward software, iPSC can be quantified easily and rapidly [103]. After freezing, it is good practice to thaw one cryovial of each batch of iPSC clones (frozen on the same day) directly after the cells are frozen (or periodically, at other time points) to assure that the cells attach and recover well, thus confirming a good cryopreservation process. In our laboratory, we observed that iPSC started to attach to Matrigel ${ }^{\mathrm{TM}}$-coated cell culture dishes approximately within 30 min after plating (on a feeder-free, Matrigel ${ }^{\mathrm{TM}}$ coating; very roughly estimated, $50 \%$ of all iPSC colonies should be at least partially attached after $30 \mathrm{~min}$ ). If they attach significantly later, it indicates that some factors have not been optimized, that a problem has occurred during the freezing/thawing process, or that the iPSC were damaged during storage or transport.

\subsection{Preventing the Disruption of Cell Aggregates}

Throughout the entire process of freezing and thawing, cell aggregates can easily become disrupted, resulting in single cells, which in turn reduces the chances of good cell recovery after thawing. iPSC survival is supported by cell-cell contacts from neighboring cells [37]. When iPSC are singularized, the missing contacts can lead to poor cell survival. (When iPSC are singularized on purpose using, for example, Accutase ${ }^{\mathrm{TM}}$, then further protocol steps would be necessary, which are not discussed in this review). The disruption of cell aggregates can happen, for example, through an overly harsh pipetting or by using an unsuitable pipette tip with a lumen that is too small for a proper passaging of the iPSC (e.g., a P1000 $\mu \mathrm{L}$ pipette tip, often blue colored for mechanical micropipettes). Pipetting iPSC through a tip with a lumen that is too small increases the shearing powers, which can in turn lead to the disruption of the cell clumps. Thus, such a pipette tip should not be used, or if so, it should only be used with care, and the possible disruption of cell clumps should be monitored under a microscope. Using $1 \mathrm{~mL}, 2 \mathrm{~mL}, 5 \mathrm{~mL}$, or $10 \mathrm{~mL}$ serological glass or plastic pipettes mostly prevents the disruption of cell aggregates because these pipettes usually have a larger lumen, which reduces shearing powers. Once the singularization of cells occured, a way to prevent cell death is by adding ROCK inhibitor and plating the cells onto a smaller surface (smaller wells), which forces the cells to become attached in closer proximity to each other, which in turn results in more cell-cell contacts, thus supporting cell survival [31,37,42,58,104,105].

\subsection{Effects of the ROCK Inhibitor}

As already outlined in other chapters of this review, the use of the ROCK inhibitor plays an important role when working with iPSC [37,56-58,106]. A final concentration of $10 \mu \mathrm{M}$ ROCK inhibitor is often added to the cell culture medium during thawing to help the survival of potentially singularized cells [31,37,42,58,104,105]. For better cell survival of iPSC upon thawing, it is recommended and usually sufficient to leave the ROCK inhibitor only for $24 \mathrm{~h}$ in the cell culture medium before withdrawing it [42]. It is possible to omit the ROCK inhibitor if all other factors are optimized during freezing, storage, and thawing, if the iPSC are not dissociated to single cells, if the cell seeding density is high enough, and if good quality iPSC are used. Since the quality is sometimes unknown, such as when cells are received from other laboratories or cell banks, it is advisable to add ROCK inhibitor to reduce the risk of sample loss. It was shown by Maldonado and colleagues that the ROCK inhibitor Y-27632 primed human iPSC to selectively differentiate towards the mesendodermal lineage [107]. Y-27632 affected the cell cytoskeleton and cell-cell junction proteins. It induced human iPSC to undergo EMT (epithelial-to-mesenchymal transition)like changes, which predisposed the cells to differentiate towards the mesendodermal lineage. This was accompanied by a disruption of the actin and E-cadherin organization, resulting in the inhibition of ectodermal differentiation. This has important implications 
for differentiation protocols. While a prolonged treatment of iPSC with Y-27632 can help to differentiate the cells into cell types of the mesendoderm, it may block their differentiation into ectodermal target cell types such as neurons [107]. Morphologically, the disruption of the actin and E-cadherin organization of the iPSC and ESC (in the presence of Y-27632) is visible in less compact colonies, consisting of cells, which are slightly increased in size and which have a changed shape. This change in morphology is temporary as long as the ROCK inhibitor is on the cells, which is reversed after Y-27632 withdrawal [108]

\subsection{Preventing Osmotic Shock during Thawing}

During thawing, a sudden change in the extracellular osmolarity can induce osmotic stress, which reduces cell viability after thawing $[109,110]$. Our assumption that iPSC are osmotically shocked during thawing is based on the observation in spermatozoa that are known to be susceptible to osmotic shock during freezing and thawing [111-114]. In human spermatozoa, osmotic shock during thawing could be reduced by a stepwise reduction of the osmolality in a series of $25 \mathrm{mOsm}$ steps [92]. The European Bank for induced pluripotent stem cells (EBiSC) recommends adding medium drop by drop to iPSC in order to minimize osmotic shock during thawing, and they stress in their protocol that this is a crucial step (https: / / ebisc.org/docs/ebisc/EBiSCProtocolforuseofiPSCv3.pdf (accessed on 15 February 2022). To reduce the likelihood of osmotic shock, after thawing a cryovial with iPSC at $37^{\circ} \mathrm{C}$ in a water bath, the cells should first be placed in a $15 \mathrm{~mL}$ conical tube, and then the cell culture medium should be added slowly in a dropwise manner. When the cell culture medium is put into the conical tube first and then the cells are added abruptly, it is more likely that the cells will suffer damage by osmotic shock. The following protocol steps are based on our own experience in the recent years after having worked with iPSC. These steps take some time, but we observed that they result in slightly better cell survival. We observed that at least $15 \%$ more cells survived compared to conventional thawing protocols (where the medium was not added stepwise and where no waiting time was provided to slowly equilibrate the osmotic pressure inside and outside of the cells) and we attribute this to a minimized osmotic shock that is accomplished by a stepwise procedure: After thawing one cryovial with iPSC (frozen in $1 \mathrm{~mL}$ freezing solution, e.g., $900 \mu \mathrm{L}$ StemFlex ${ }^{\mathrm{TM}}$ or mTeSR $1^{\mathrm{TM}}$ medium plus $100 \mu \mathrm{L}$ DMSO), we first place the cells in a $15 \mathrm{~mL}$ conical tube, then we add the following volumes of medium, slowly and in a dropwise manner-add $1 \mathrm{~mL}$ of medium, wait for $5 \mathrm{~min}$ (to slowly equilibrate the osmotic pressure inside and outside of the cells), add another $2 \mathrm{~mL}$, wait for $5 \mathrm{~min}$, and finally, add $4 \mathrm{~mL}$ and wait for another $5 \mathrm{~min}$. Then, we spin down the cells at $200 \mathrm{~g}$ for $2.5 \mathrm{~min}$, aspirate the supernatant, and carefully, without disrupting the cell aggregates too much, resuspend the cell pellet in $2 \mathrm{~mL}$ of cell culture medium (mostly in the presence of $10 \mu \mathrm{M}$ ROCK inhibitor), and seed the cells in one well of a six-well plate previously coated with Matrigel $^{\mathrm{TM}}$.

\subsection{Identifying Problems Causing Insufficient Cell Recovery}

We suggest taking the following steps whenever iPSC cannot be recovered after thawing. If this is the case, it is often not clear initially what causes this problem. If only one clone is thawed and this clone does not attach properly to the coated cell culture plate after thawing or does not proliferate well, it will not be clear at first glance which of the many possible factors (sub-optimal freezing process, coating, etc.) might be causing this problem. For this reason, we recommend troubleshooting by following a certain order of steps in order to solve the problem more rapidly. Several factors must be considered to find out why iPSC do not show sufficient attachment or survival upon thawing. An effective way to tackle this, is to first find out if the freezing or the thawing procedure is the problem, or if an intrinsic property of the cells themselves, e.g., a clonal effect, is the problem. A suitable strategy to rule out the possibility that not a clonal effect is causing the difference in cell recovery after thawing, is to thaw at least three different iPSC clones in parallel, which have preferably been frozen on the same day (Figure 1a). Further insight into the problem can be gained by thawing three cryovials of an identical iPSC clone, frozen on different days 
(Figure 1b). Clone-to-clone variability of iPSC occurs occasionally; however, we estimate that freezing or thawing problems take place more frequently than clonal problems, given the fact that during freezing/thawing, many single protocol steps exist, which alone or in combination can lead to insufficient cell recovery after thawing and plating if carried out erroneously or if the protocols are not optimized $[115,116]$.

(a) Thawing three different iPSC clones frozen on the same day

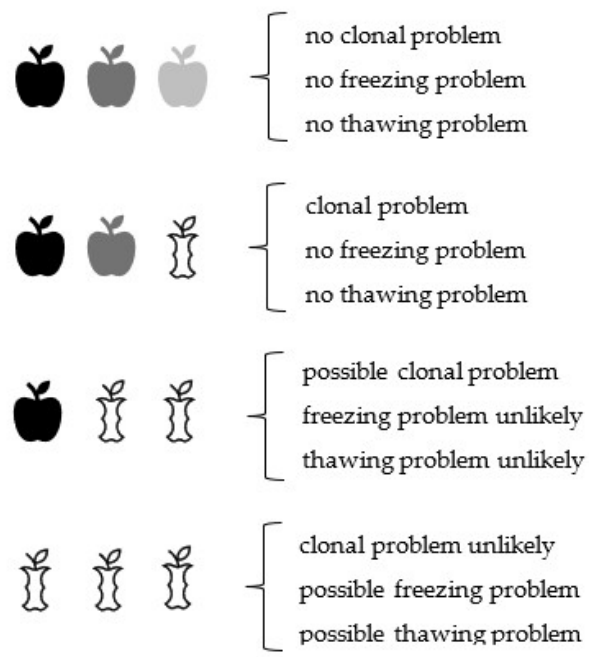

(b) Thawing three cryovials of the same iPSC clone frozen on different days

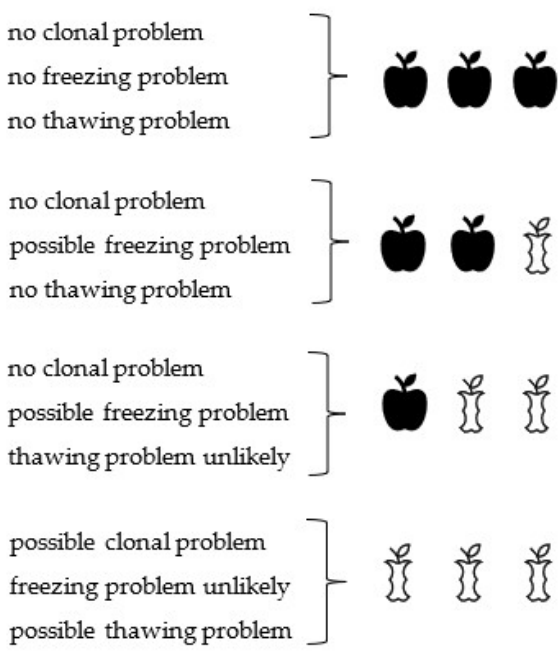

Figure 1. Decision model that helps to identify problems underlying insufficient cell attachment/recovery upon thawing. First steps that can be taken to find out if a bad attachment/recovery of iPSC is caused (1) by clonal cell properties, (2) by an unoptimized freezing protocol, or (3) by an unoptimized thawing protocol. After having narrowed down the problem using this decision model, it will be easier to identify further issues more exactly. From this thawing pattern of good/bad cell attachment, one can continue to further identify sources of error systematically. (a) By thawing three cryovials containing different iPSC clones, frozen on the same day, information can be obtained about clone-to-clone variability and about the freezing/thawing efficiency. (b) By thawing three cryovials of the same iPSC clone, one can get information about this single clone and about the freezing/ thawing efficiency. The term "freezing problem" encompasses all steps associated with the entire freezing process, such as being out of the log growth phase before freezing, etc. The term "thawing problem" encompasses all steps associated with the entire thawing process, which includes coating problems, etc. Conclusions, given in curved parentheses, are careful approximations of what has actually happened during freezing/thawing. 6 clone 1,6 clone 2, clone 3 , 造 compromised clone.

\subsection{Supplementary Information}

Poor survival of iPSC after thawing and plating can be caused by many factors. We recommend a troubleshooting approach (Supplementary Materials, Figure S1) to identify the underlying problem(s) more quickly. Additionally, we provide information about the shipping of iPSC. iPSC should be shipped according to specific guidelines. A summary of crucial steps can be found in the section Shipping of iPSC of the Supplementary Materials and is available online at https: / / www.mdpi.com/article/10.3390/cells11050799/s1 (accessed on 10 February 2022).

\section{Conclusions}

To make it more likely that iPSC can be recovered successfully after thawing, both the freezing and thawing protocols should be optimized. The more factors are optimized during cryopreservation and thawing, the higher the chances are of a successful cell recovery after thawing. It also must be taken into consideration that small deviations from the freezing 
and thawing protocols, which alone do not necessarily cause thawing problems, in combination can add up to a failure in cell recovery after thawing and plating. Whenever there is a problem with cell recovery after the thawing of iPSC, it is initially not clear what it is caused by because there are many factors involved, all of which can contribute to the fact that cells cannot be recovered. Some factors are more important than others for a successful cell recovery, and a general agreement on what is more or less important does not really exist for all these factors. Those factors that we regard as important are compiled in Tables 1, 2, and summarized in the Supplementary Information in more detail. According to the literature, together with our own hands-on experience, we consider the following factors as essential: (i) freezing of iPSC in the logarithmic growth phase, (ii) handling the cells gently, without disrupting the cell aggregates too much, during freezing and thawing, (iii) adding ROCK inhibitor to the cell culture medium during thawing (although it is possible to thaw iPSC without ROCK inhibitor, its use is often recommended, especially if other factors are not optimized, such as working with singularized cells instead of cell aggregates), (iv) maintaining a high cell seeding density during thawing, (v) preventing osmotic shock during thawing, (vi) using an optimized coating protocol (e.g., Matrigel ${ }^{\mathrm{TM}}$ prepared according to the manufacturer's guidelines). Using an optimized thawing procedure is particularly important whenever precious, rare, or expensive iPSC clones are meant to be recovered. Figure 1 summarizes first steps that can be taken to find out if a bad attachment/recovery of iPSC after thawing is caused (1) by clonal cell properties, (2) by an unoptimized freezing protocol, or (3) by an unoptimized thawing protocol. From the resulting thawing pattern of good/bad cell attachment (outlined in Figure 1), one can continue to further identify sources of error systematically. The quality of frozen iPSC is often unknown (for example, when they are delivered from an unknown laboratory/cryobank). Therefore, it is advisable to apply the best possible thawing protocol available and to handle the cells as carefully as possible in order to increase the chance of a good cell recovery. We observed in our laboratory that approximately during the first 1-3 passages directly after reprogramming, a relatively high degree of spontaneous differentiation usually occurs, that the cells are more sensitive and are thus more prone to die. Trying to thaw iPSC, which were frozen at these early passages after reprogramming, can result in low cell recovery after thawing. Extra care must be taken upon thawing of such early-passage cell clones. Alternatively, to circumvent such problems, iPSC can be kept longer in culture, passaged a few more times, and then frozen at later passages (they become more stable after a few passages). In summary, if any thawing problems occur, we suggest the optimization of the essential factors outlined above (factors i-vi of this Conclusion section). Once they are optimized, further possible issues can be troubleshooted, should that become necessary.

Supplementary Materials: The following supporting information can be downloaded at: https:// www.mdpi.com/article/10.3390/cells11050799/s1, Figure S1: Important steps for cryopreservation, thawing and their optimization options.

Author Contributions: M.U. wrote the manuscript. F.E. took part in manuscript preparation, revision, and acquisition of financial support. M.E. took part in manuscript preparation, revision, and acquisition of financial support. All authors have read and agreed to the published version of the manuscript.

Funding: This research was funded by FONDECYT $\mathrm{N}^{\circ} 1200287$ to FE and by FONDECYT $\mathrm{N}^{\circ}$ 1200308 to ME. FONDECYT is the abbreviation for Fondo Nacional de Desarrollo Científico y Tecnológico. FONDECYT is the main public fund of the Chilean Government. This national fund for scientific and technological development aims to promote the development of basic scientific and technological research.

Data Availability Statement: Protocols for freezing and thawing of iPSC used in our laboratory are available upon request.

Acknowledgments: We thank Joachim Pavel for information about the CASY ${ }^{\circledR}$ Cell Counter \& Analyzer. Furthermore, we thank Thorsten Rieling for information about the Agilent NovoCyte flow cytometers. 
Conflicts of Interest: The authors F.E. and M.E. declare no conflicts of interest. When the manuscript of this review article was submitted, MU was employed at OLS OMNI Life Science, which is the manufacturer of the CASY ${ }^{\circledR}$ Cell Counter \& Analyzer and a distributor of Agilent instruments in Germany.

$\begin{array}{ll}\text { Abbreviations } & \\ \text { iPSC } & \begin{array}{l}\text { induced pluripotent stem cells } \\ \text { embryonic stem cells }\end{array} \\ \text { ESC } & \text { logarithmic cell growth phase (synonym: exponential phase) } \\ \text { log phase } & \text { Rho-associated, coiled-coil containing protein kinase inhibitor } \\ \text { ROCK inhibitor } & \text { fetal bovine serum } \\ \text { FBS } & \text { dimethyl sulfoxide } \\ \text { DMSO } & \text { knockout serum replacement } \\ \text { KSR } & \text { Dulbecco's Modified Eagle's Medium/Ham's F-12 } \\ \text { DMEM/F12 } & \text { ethylenediaminetetraacetic acid } \\ \text { EDTA } & \text { phosphate-buffered saline } \\ \text { PBS } & \text { standard operating procedure } \\ \text { SOP } & \text { CryoLogic vitrification method } \\ \text { CVM } & \end{array}$

\section{References}

1. Ohnuki, M.; Takahashi, K. Present and future challenges of induced pluripotent stem cells. Philos. Trans. R. Soc. B Biol. Sci. 2015, 370, 20140367. [CrossRef] [PubMed]

2. Doss, M.X.; Sachinidis, A. Current Challenges of iPSC-Based Disease Modeling and Therapeutic Implications. Cells $2019,8,403$. [CrossRef] [PubMed]

3. Drexler, H.G.; Uphoff, C.C. Mycoplasma contamination of cell cultures: Incidence, sources, effects, detection, elimination, prevention. Cytotechnology 2002, 39, 75-90. [CrossRef] [PubMed]

4. Uphoff, C.C.; Drexler, H.G. Detection of mycoplasma contamination in cell cultures. Curr. Protoc. Mol. Biol. 2014, 2014, 28.4.1-28.4.14. [CrossRef]

5. Uphoff, C.C.; Drexler, H.G. Elimination of Mycoplasmas from Infected Cell Lines Using Antibiotics. In Cancer Cell Culture; Humana Press: Totowa, NJ, USA, 2011; Volume 731, pp. 105-114. [CrossRef]

6. Acker, J.P.; McGann, L.E. Protective effect of intracellular ice during freezing? Cryobiology 2003, 46, 197-202. [CrossRef]

7. Lawson, A.; Ahmad, H.; Sambanis, A. Cytotoxicity effects of cryoprotectants as single-component and cocktail vitrification solutions. Cryobiology 2011, 62, 115-122. [CrossRef]

8. Fleming Glass, K.K.; Longmire, E.K.; Hubel, A. Optimization of a microfluidic device for diffusion-based extraction of dmso from a cell suspension. Int. J. Heat Mass Transf. 2008, 51, 5749. [CrossRef]

9. MAZUR, P. Kinetics of Water Loss from Cells at Subzero Temperatures and the Likelihood of Intracellular Freezing. J. Gen. Physiol. 1963, 47, 347. [CrossRef]

10. Mazur, P. Cryobiology: The freezing of biological systems. Science 1970, 168, 939-949. [CrossRef]

11. Mazur, P.; Leibo, S.P.; Chu, E.H.Y. A two-factor hypothesis of freezing injury: Evidence from Chinese hamster tissue-culture cells. Exp. Cell Res. 1972, 71, 345-355. [CrossRef]

12. He, X. Thermostability of Biological Systems: Fundamentals, Challenges, and Quantification. Open Biomed. Eng. J. 2011, 5, 47. [CrossRef] [PubMed]

13. Hayashi, Y.; Horiguchi, I.; Kino-oka, M.; Sugiyama, H. Slow freezing process design for human induced pluripotent stem cells by modeling intracontainer variation. Comput. Chem. Eng. 2020, 132, 106597. [CrossRef]

14. Hayashi, Y.; Horiguchi, I.; Kino-oka, M.; Sugiyama, H. Model-based assessment of temperature profiles in slow freezing for human induced pluripotent stem cells. Comput. Chem. Eng. 2021, 144, 107150. [CrossRef]

15. Hunt, C.J. Cryopreservation of Human Stem Cells for Clinical Application: A Review. Transfus. Med. Hemother. 2011, 38, 107-123. [CrossRef]

16. Ware, C.B.; Nelson, A.M.; Blau, C.A. Controlled-rate freezing of human ES cells. Biotechniques 2005, 38, 879-883. [CrossRef]

17. Li, R.; Yu, G.; Azarin, S.M.; Hubel, A. Freezing Responses in DMSO-Based Cryopreservation of Human iPS Cells: Aggregates Versus Single Cells. Tissue Eng. Part C. Methods 2018, 24, 289-299. [CrossRef]

18. Konc, J.; Kanyo, K.; Varga, E.; Kriston, R.; Cseh, S. Oocyte cryopreservation: The birth of the first Hungarian babies from frozen oocytes. J. Assist. Reprod. Genet. 2008, 25, 349. [CrossRef]

19. Paynter, S.J. A rational approach to oocyte cryopreservation. Reprod. Biomed. Online 2005, 10, 578-586. [CrossRef]

20. Gallardo, M.; Saenz, J.; Risco, R. Human oocytes and zygotes are ready for ultra-fast vitrification after 2 minutes of exposure to standard cpA solutions. Sci. Rep. 2019, 9, 15986. [CrossRef]

21. T'joen, V.; De Grande, L.; Declercq, H.; Cornelissen, M. An Efficient, Economical Slow-Freezing Method for Large-Scale Human Embryonic Stem Cell Banking. Stem Cells Dev. 2011, 21, 721-728. [CrossRef] [PubMed] 
22. Meneghel, J.; Kilbride, P.; Morris, J.G.; Fonseca, F. Physical events occurring during the cryopreservation of immortalized human T cells. PLoS ONE 2019, 14, e0217304. [CrossRef] [PubMed]

23. Baust, J.M.; Corwin, W.L.; VanBuskirk, R.; Baust, J.G. Biobanking: The future of cell preservation strategies. In Biobanking in the 21st Century; Springer International Publishing: New York, NY, USA, 2015; pp. 37-53, ISBN 9783319205793.

24. Baust, J.G.; Gage, A.A.; Klossner, D.; Clarke, D.; Miller, R.; Cohen, J.; Katz, A.; Polascik, T.; Clarke, H.; Baust, J.M. Issues critical to the successful application of cryosurgical ablation of the prostate. Technol. Cancer Res. Treat. 2007, 6, 97-109. [CrossRef] [PubMed]

25. Fan, Q.; Dou, M.; Mao, J.; Hou, Y.; Liu, S.; Zhao, L.; Lv, J.; Liu, Z.; Wang, Y.; Rao, W.; et al. Strong Hydration Ability of Silk Fibroin Suppresses Formation and Recrystallization of Ice Crystals During Cryopreservation. Biomacromolecules 2021, 23, 478-486. [CrossRef]

26. Li, W.; Yang, G.; Zhang, A.; Xu, L.X. Numerical Study of Cell Cryo-Preservation: A Network Model of Intracellular Ice Formation. PLOS ONE 2013, 8, e58343. [CrossRef]

27. Rowley, S.D.; Byrne, D.V. Low-temperature storage of bone marrow in nitrogen vapor-phase refrigerators: Decreased temperature gradients with an aluminum racking system. Transfusion 1992, 32, 750-754. [CrossRef]

28. Yuan, Y.; Yang, Y.; Tian, Y.; Park, J.; Dai, A.; Roberts, R.M.; Liu, Y.; Han, X. Efficient long-term cryopreservation of pluripotent stem cells at $-80^{\circ} \mathrm{C}$. Sci. Rep. 2016, 6, 34476. [CrossRef]

29. Hartung, O.; Huo, H.; Daley, G.Q.; Schlaeger, T.M. Clump passaging and expansion of human embryonic and induced pluripotent stem cells on mouse embryonic fibroblast feeder cells. Curr. Protoc. Stem Cell Biol. 2010, 14, 1C.10.1-1C.10.15. [CrossRef]

30. Cruvinel, E.; Ogusuku, I.; Cerioni, R.; Rodrigues, S.; Gonçalves, J.; Góes, M.E.; Alvim, J.M.; Silva, A.C.; de Souza Lino, V.; Boccardo, E.; et al. Long-term single-cell passaging of human iPSC fully supports pluripotency and high-efficient trilineage differentiation capacity. SAGE Open Med. 2020, 8, 205031212096645. [CrossRef]

31. Baek, S.K.; Cho, Y.S.; Kim, I.S.; Jeon, S.B.; Moon, D.K.; Hwangbo, C.; Choi, J.W.; Kim, T.S.; Lee, J.H. A Rho-Associated Coiled-Coil Containing Kinase Inhibitor, Y-27632, Improves Viability of Dissociated Single Cells, Efficiency of Colony Formation, and Cryopreservation in Porcine Pluripotent Stem Cells. Cell. Reprogram. 2019, 21, 37-50. [CrossRef]

32. Rizzino, A. Stimulating progress in regenerative medicine: Improving the cloning and recovery of cryopreserved human pluripotent stem cells with ROCK inhibitors. Regen. Med. 2010, 5, 799. [CrossRef] [PubMed]

33. Rivera, T.; Zhao, Y.; Ni, Y.; Wang, J. Human-Induced Pluripotent Stem Cell Culture Methods Under cGMP Conditions. Curr. Protoc. Stem Cell Biol. 2020, 54, e117. [CrossRef]

34. Trish, E.; Dimos, J.; Eggan, K. Freezing human ES cells. J. Vis. Exp. 2006, 1, e50. [CrossRef] [PubMed]

35. Turner, J.; Quek, L.E.; Titmarsh, D.; Krömer, J.O.; Kao, L.P.; Nielsen, L.; Wolvetang, E.; Cooper-White, J. Metabolic profiling and flux analysis of MEL-2 human embryonic stem cells during exponential growth at physiological and atmospheric oxygen concentrations. PLoS ONE 2014, 9, e112757. [CrossRef] [PubMed]

36. Liu, W.; Chen, G. Cryopreservation of human pluripotent stem cells in defined medium. Curr. Protoc. Stem Cell Biol. 2014, 2014, 1c.17.1-1c.17.13. [CrossRef]

37. Beers, J.; Gulbranson, D.R.; George, N.; Siniscalchi, L.I.; Jones, J.; Thomson, J.A.; Chen, G. Passaging and colony expansion of human pluripotent stem cells by enzyme-free dissociation in chemically defined culture conditions. Nat. Protoc. 2012, 7 , 2029-2040. [CrossRef]

38. Chatterjee, I.; Li, F.; Kohler, E.E.; Rehman, J.; Malik, A.B.; Wary, K.K. Induced pluripotent stem (iPS) cell culture methods and induction of differentiation into endothelial cells. In Methods in Molecular Biology; Humana Press Inc.: New York, NY, USA, 2016; Volume 1357, pp. 311-327.

39. Tamm, C.; Galitó, S.P.; Annerén, C. A comparative study of protocols for mouse embryonic stem cell culturing. PLoS ONE 2013, 8, e81156. [CrossRef]

40. Mummery, C.L.; Zhang, J.; Ng, E.S.; Elliott, D.A.; Elefanty, A.G.; Kamp, T.J. Differentiation of Human ES and iPS Cells to Cardiomyocytes: A Methods Overview. Circ. Res. 2012, 111, 344. [CrossRef]

41. Morris, C.B. Cryopreservation of animal and human cell lines. Methods Mol. Biol. 1995, 38, 179-187. [CrossRef]

42. Claassen, D.A.; Desler, M.M.; Rizzino, A. ROCK inhibition enhances the recovery and growth of cryopreserved human embryonic stem cells and human induced pluripotent stem cells. Mol. Reprod. Dev. 2009, 76, 722-732. [CrossRef]

43. Wang, J.; Hao, J.; Bai, D.; Gu, Q.; Han, W.; Wang, L.; Tan, Y.; Li, X.; Xue, K.; Han, P.; et al. Generation of clinical-grade human induced pluripotent stem cells in Xeno-free conditions. Stem Cell Res. Ther. 2015, 6, 223. [CrossRef] [PubMed]

44. Miyamoto, Y.; Noguchi, H.; Yukawa, H.; Oishi, K.; Matsushita, K.; Iwata, H.; Hayashi, S. Cryopreservation of Induced Pluripotent Stem Cells. Cell Med. 2012, 3, 89. [CrossRef] [PubMed]

45. Nakagawa, M.; Taniguchi, Y.; Senda, S.; Takizawa, N.; Ichisaka, T.; Asano, K.; Morizane, A.; Doi, D.; Takahashi, J.; Nishizawa, M.; et al. A novel efficient feeder-free culture system for the derivation of human induced pluripotent stem cells. Sci. Rep. 2014, 4, 3594. [CrossRef] [PubMed]

46. Holm, F.; Ström, S.; Inzunza, J.; Baker, D.; Strömberg, A.M.; Rozell, B.; Feki, A.; Bergström, R.; Hovatta, O. An effective serumand xeno-free chemically defined freezing procedure for human embryonic and induced pluripotent stem cells. Hum. Reprod. 2010, 25, 1271. [CrossRef] [PubMed]

47. Wagner, K.; Welch, D. Cryopreserving and recovering of human iPS cells using complete knockout serum replacement feeder-free medium. J. Vis. Exp. 2010, 41, e2237. [CrossRef] 
48. Wagner, K.; Welch, D. Feeder-free adaptation, culture and passaging of human IPS cells using complete knockout serum replacement feeder-free medium. J. Vis. Exp. 2010, 41, e2236. [CrossRef]

49. Chen, G.; Gulbranson, D.R.; Hou, Z.; Bolin, J.M.; Ruotti, V.; Probasco, M.D.; Smuga-Otto, K.; Howden, S.E.; Diol, N.R.; Propson, N.E.; et al. Chemically defined conditions for human iPSC derivation and culture. Nat. Methods 2011, 8, 424-429. [CrossRef]

50. Wagh, V.; Meganathan, K.; Jagtap, S.; Gaspar, J.A.; Winkler, J.; Spitkovsky, D.; Hescheler, J.; Sachinidis, A. Effects of Cryopreservation on the Transcriptome of Human Embryonic Stem Cells After Thawing and Culturing. Stem Cell Rev. Rep. 2011, 7, 506-517. [CrossRef]

51. Ha, S.Y.; Jee, B.C.; Suh, C.S.; Kim, H.S.; Oh, S.K.; Kim, S.H.; Moon, S.Y. Cryopreservation of human embryonic stem cells without the use of a programmable freezer. Hum. Reprod. 2005, 20, 1779-1785. [CrossRef]

52. Fernandes, S.; Khan, N.; Kale, V.; Limaye, L. Catalase incorporation in freezing mixture leads to improved recovery of cryopreserved iPSC lines. Cryobiology 2019, 90, 21-29. [CrossRef]

53. Schuldiner, M.; Yanuka, O.; Itskovitz-Eldor, J.; Melton, D.A.; Benvenisty, N. Effects of eight growth factors on the differentiation of cells derived from human embryonic stem cells. Proc. Natl. Acad. Sci. USA 2000, 97, 11307-11312. [CrossRef] [PubMed]

54. Galvao, J.; Davis, B.; Tilley, M.; Normando, E.; Duchen, M.R.; Cordeiro, M.F. Unexpected low-dose toxicity of the universal solvent DMSO. FASEB J. 2014, 28, 1317-1330. [CrossRef] [PubMed]

55. Vogel, K.G. Effects of hyaluronidase, trypsin, and EDTA on surface composition and topography during detachment of cells in culture. Exp. Cell Res. 1978, 113, 345-357. [CrossRef]

56. Katkov, I.I.; Kan, N.G.; Cimadamore, F.; Nelson, B.; Snyder, E.Y.; Terskikh, A.V. DMSO-Free Programmed Cryopreservation of Fully Dissociated and Adherent Human Induced Pluripotent Stem Cells. Stem Cells Int. 2011, 2011, 981606 . [CrossRef]

57. Reichard, A.; Asosingh, K. Best Practices for Preparing a Single Cell Suspension from Solid Tissues for Flow Cytometry. Wiley 2018, 95, 219-226. [CrossRef]

58. Li, X.; Krawetz, R.; Liu, S.; Meng, G.; Rancourt, D.E. ROCK inhibitor improves survival of cryopreserved serum/feeder-free single human embryonic stem cells. Hum. Reprod. 2009, 24, 580-589. [CrossRef]

59. iPSC-Based Modeling of RAG2 Severe Combined Immunodeficiency Reveals Multiple T Cell Developmental Arrests I Elsevier Enhanced Reader. Available online: https: / / reader.elsevier.com/reader/sd / pii/S2213671119304497?token=0FE955BBA6552C8 E047859237B924974C7D810800B8E49ABCDF49F4FEE7C1BF9152E41278849C1BFFDDCE1EB5F8CF139\&originRegion=eu-west1 \&originCreation=20220206205918 (accessed on 6 February 2022).

60. Kibschull, M.; Mileikovsky, M.; Michael, I.P.; Lye, S.J.; Nagy, A. Human embryonic fibroblasts support single cell enzymatic expansion of human embryonic stem cells in xeno-free cultures. Stem Cell Res. 2011, 6, 70-82. [CrossRef]

61. Hedges, E.C.; Topp, S.; Shaw, C.E.; Nishimura, A.L. Generation of six induced pluripotent stem cell lines from patients with amyotrophic lateral sclerosis with associated genetic mutations in either FUS or ANXA11. Stem Cell Res. 2021, $52,102246$. [CrossRef]

62. Beers, J.; Linask, K.L.; Chen, J.A.; Siniscalchi, L.I.; Lin, Y.; Zheng, W.; Rao, M.; Chen, G. A cost-effective and efficient reprogramming platform for large-scale production of integration-free human induced pluripotent stem cells in chemically defined culture. Sci. Rep. 2015, 5, 11319. [CrossRef]

63. Ludwig, T.E.; Bergendahl, V.; Levenstein, M.E.; Yu, J.; Probasco, M.D.; Thomson, J.A. Feeder-independent culture of human embryonic stem cells. Nat. Methods 2006, 3, 637-646. [CrossRef]

64. Ludwig, T.E.; Levenstein, M.E.; Jones, J.M.; Berggren, W.T.; Mitchen, E.R.; Frane, J.L.; Crandall, L.J.; Daigh, C.A.; Conard, K.R.; Piekarczyk, M.S.; et al. Derivation of human embryonic stem cells in defined conditions. Nat. Biotechnol. 2006, $24,185-187$. [CrossRef] [PubMed]

65. Castro-Viñuelas, R.; Sanjurjo-Rodríguez, C.; Piñeiro-Ramil, M.; Rodríguez-Fernández, S.; López-Baltar, I.; Fuentes-Boquete, I.; Blanco, F.J.; Díaz-Prado, S. Tips and tricks for successfully culturing and adapting human induced pluripotent stem cells. Mol. Ther.-Methods Clin. Dev. 2021, 23, 569-581. [CrossRef] [PubMed]

66. Rienzi, L.; Gracia, C.; Maggiulli, R.; Labarbera, A.R.; Kaser, D.J.; Ubaldi, F.M.; Vanderpoel, S.; Racowsky, C. Oocyte, embryo and blastocyst cryopreservation in art: Systematic review and meta-Analysis comparing slow-freezing versus vitrification to produce evidence for the development of global guidance. Hum. Reprod. Update 2017, 23, 139-155. [CrossRef] [PubMed]

67. Hunt, C.J. Cryopreservation: Vitrification and Controlled Rate Cooling. Methods Mol. Biol. 2017, 1590, 41-77. [CrossRef]

68. Costa, G.M.J.; Avelar, G.F.; Lacerda, S.M.S.N.; Figueiredo, A.F.A.; Tavares, A.O.; Rezende-Neto, J.V.; Martins, F.G.P.; França, L.R. Horse spermatogonial stem cell cryopreservation: Feasible protocols and potential biotechnological applications. Cell Tissue Res. 2017, 370, 489-500. [CrossRef]

69. Panagiotidis, Y.; Vanderzwalmen, P.; Prapas, Y.; Kasapi, E.; Goudakou, M.; Papatheodorou, A.; Passadaki, T.; Petousis, S.; Nikolettos, N.; Veletza, S.; et al. Open versus closed vitrification of blastocysts from an oocyte-donation programme: A prospective randomized study. Reprod. Biomed. Online 2013, 26, 470-476. [CrossRef]

70. Seki, S.; Mazur, P. The Dominance of Warming Rate Over Cooling Rate in the Survival of Mouse Oocytes Subjected to a Vitrification Procedure. Cryobiology 2009, 59, 75. [CrossRef]

71. A review of best practices of rapid-cooling vitrification for oocytes and embryos: A committee opinion. Fertil. Steril. 2021, 115, 305-310. [CrossRef] 
72. Fahy, G.M.; Wowk, B.; Wu, J.; Phan, J.; Rasch, C.; Chang, A.; Zendejas, E. Cryopreservation of organs by vitrification: Perspectives and recent advances. Cryobiology 2004, 48, 157-178. [CrossRef]

73. Fahy, G.M.; Wowk, B.; Wu, J.; Paynter, S. Improved vitrification solutions based on the predictability of vitrification solution toxicity. Cryobiology 2004, 48, 22-35. [CrossRef]

74. Szurek, E.A.; Eroglu, A. Comparison and Avoidance of Toxicity of Penetrating Cryoprotectants. PLoS ONE 2011, 6, e27604. [CrossRef] [PubMed]

75. Fowler, A.; Toner, M. Cryo-injury and biopreservation. Ann. N. Y. Acad. Sci. 2005, 1066, 119-135. [CrossRef] [PubMed]

76. Boutron, P. Comparison with the theory of the kinetics and extent of ice crystallization and of the glass-forming tendency in aqueous cryoprotective solutions. Cryobiology 1986, 23, 88-102. [CrossRef]

77. He, X.; Park, E.Y.H.; Fowler, A.; Yarmush, M.L.; Toner, M. Vitrification by Ultra-fast Cooling at a Low Concentration of Cryoprotectants in a Quartz Microcapillary: A Study Using Murine Embryonic Stem Cells. Cryobiology 2008, 56, 223. [CrossRef] [PubMed]

78. Kaindl, J.; Meiser, I.; Majer, J.; Sommer, A.; Krach, F.; Katsen-Globa, A.; Winkler, J.; Zimmermann, H.; Neubauer. J.C.; Winner, B. Zooming in on Cryopreservation of hiPSCs and Neural Derivatives: A Dual-Center Study Using Adherent Vitrification. Stem Cells Transl. Med. 2019, 8, 247-259. [CrossRef]

79. Zhang, Y.; Liu, H.; Liu, Z.; Long, P.; Zhao, X.; Li, Q.; Huang, Y.; Ma, Y. Cryopreservation of human induced pluripotent stem cells by using a new CryoLogic vitrification method. Cryobiology 2021, 98, 210-214. [CrossRef]

80. Xiong, S.; Liu, J.X.; Gao, Y.; Liu, W.W.; Wu, L.H.; Han, W.; Zhang, X.D.; Han, S.B.; Liu, D.Y.; Huang, G.N. Shortened equilibration time can compromise clinical outcomes in human embryo vitrification. Hum. Fertil. 2016, 19, 114-119. [CrossRef]

81. Vanderzwalmen, P.; Ectors, F.; Grobet, L.; Prapas, Y.; Panagiotidis, Y.; Vanderzwalmen, S.; Stecher, A.; Frias, P.; Liebermann, J.; Zech, N.H. Aseptic vitrification of blastocysts from infertile patients, egg donors and after IVM. Reprod. Biomed. Online 2009, 19, 700-707. [CrossRef]

82. Wang, W.H.; Meng, L.; Hackett, R.J.; Odenbourg, R.; Keefe, D.L. Limited recovery of meiotic spindles in living human oocytes after cooling-rewarming observed using polarized light microscopy. Hum. Reprod. 2001, 16, 2374-2378. [CrossRef]

83. Zenzes, M.T.; Bielecki, R.; Casper, R.F.; Leibo, S.P. Effects of chilling to 0 degrees $C$ on the morphology of meiotic spindles in human metaphase II oocytes. Fertil. Steril. 2001, 75, 769-777. [CrossRef]

84. Frim, J.; Mazur, P. Interactions of cooling rate, warming rate, glycerol concentration, and dilution procedure on the viability of frozen-thawed human granulocytes. Cryobiology 1983, 20, 657-676. [CrossRef]

85. Baharvand, H.; Hosseini Salekdeh, G.; Taei, A.; Mollamohammadi, S. An efficient and easy-to-use cryopreservation protocol for human ES and iPS cells. Nat. Protoc. 2010, 5, 588-594. [CrossRef] [PubMed]

86. Pakzad, M.; Totonchi, M.; Taei, A.; Seifinejad, A.; Hassani, S.N.; Baharvand, H. Presence of a ROCK inhibitor in extracellular matrix supports more undifferentiated growth of feeder-free human embryonic and induced pluripotent stem cells upon passaging. Stem Cell Rev. Rep. 2010, 6, 96-107. [CrossRef] [PubMed]

87. Lam, M.T.; Longaker, M.T. Comparison of several attachment methods for human iPS, embryonic and adipose-derived stem cells for tissue engineering. J. Tissue Eng. Regen. Med. 2012, 6 (Suppl. S3), s80-s86. [CrossRef]

88. Miyazaki, T.; Suemori, H. Slow Cooling Cryopreservation Optimized to Human Pluripotent Stem Cells. Adv. Exp. Med. Biol. 2016, 951, 57-65. [CrossRef] [PubMed]

89. Martin-Ibañez, R.; Unger, C.; Strömberg, A.; Baker, D.; Canals, J.M.; Hovatta, O. Novel cryopreservation method for dissociated human embryonic stem cells in the presence of a ROCK inhibitor. Hum. Reprod. 2008, 23, 2744-2754. [CrossRef] [PubMed]

90. Martín-Ibáñez, R.; Strömberg, A.M.; Hovatta, O.; Canals, J.M. Cryopreservation of dissociated human embryonic stem cells in the presence of ROCK inhibitor. Chapter 1, Unit 1C.8. Curr. Protoc. Stem Cell Biol. 2009, 10, 1C.8.1-1C.8.15. [CrossRef] [PubMed]

91. Hunt, C.J. Technical Considerations in the Freezing, Low-Temperature Storage and Thawing of Stem Cells for Cellular Therapies. Transfus. Med. Hemother. 2019, 46, 134-149. [CrossRef]

92. Curry, M.R.; Watson, P.F. Osmotic effects on ram and human sperm membranes in relation to thawing injury. Cryobiology 1994, 31, 39-46. [CrossRef]

93. Culture of Established Induced Pluripotent Stem Cell Lines. Available online: https://www.protocols.io/view/culture-ofestablished-induced-pluripotent-stem-ce-bgbwjspe (accessed on 6 February 2022).

94. Jose, S.S.; Tidu, F.; Burilova, P.; Kepak, T.; Bendickova, K.; Fric, J. The Telomerase Complex Directly Controls Hematopoietic Stem Cell Differentiation and Senescence in an Induced Pluripotent Stem Cell Model of Telomeropathy. Front. Genet. 2018, 9, 345. [CrossRef]

95. Zeiger, A.S.; Hinton, B.; Van Vliet, K.J. Why the dish makes a difference: Quantitative comparison of polystyrene culture surfaces. Acta Biomater. 2013, 9, 7354-7361. [CrossRef] [PubMed]

96. Strober, W. Trypan blue exclusion test of cell viability. Appendix 3. Curr. Protoc. Immunol. 2001. [CrossRef]

97. Chan, L.L.Y.; Rice, W.L.; Qiu, J. Observation and quantification of the morphological effect of trypan blue rupturing dead or dying cells. PLoS ONE 2020, 15, e0227950. [CrossRef] [PubMed]

98. Moll, G.; Alm, J.J.; Davies, L.C.; Von Bahr, L.; Heldring, N.; Stenbeck-Funke, L.; Hamad, O.A.; Hinsch, R.; Ignatowicz, L.; Locke, M.; et al. Do cryopreserved mesenchymal stromal cells display impaired immunomodulatory and therapeutic properties? Stem Cells 2014, 32, 2430-2442. [CrossRef] [PubMed] 
99. Kovacic, B.; Rosner, M.; Schlangen, K.; Kramer, N.; Hengstschläger, M. DRUGPATH-a novel bioinformatic approach identifies DNA-damage pathway as a regulator of size maintenance in human ESCs and iPSCs. Sci. Rep. 2019, 9, 1897. [CrossRef] [PubMed]

100. Emmenegger, M.; De Cecco, E.; Hruska-Plochan, M.; Eninger, T.; Schneider, M.M.; Barth, M.; Tantardini, E.; de Rossi, P.; Bacioglu, M.; Langston, R.G.; et al. LAG3 is not expressed in human and murine neurons and does not modulate $\alpha-$ synucleinopathies. EMBO Mol. Med. 2021, 13, e14745. [CrossRef]

101. Grässer, U.; Bubel, M.; Sossong, D.; Oberringer, M.; Pohlemann, T.; Metzger, W. Dissociation of mono- and co-culture spheroids into single cells for subsequent flow cytometric analysis. Ann. Anat.-Anat. Anzeiger 2018, 216, 1-8. [CrossRef]

102. Freedman, B.S.; Keeler, E.G.; Lin, L.Y.; Cruz, N.M.; Jing, P.; Liu, Y. Optical tweezers system for live stem cell organization at the single-cell level. Biomed. Opt. Express 2018, 9, 771-779. [CrossRef]

103. Wei, C.; Lu, X.; Zou, Q.; Gong, S.; Chen, Y.; Lyu, J.; Jia, J. Generation and characterization of a human induced pluripotent stem cell line (XWHNi001-A) derived from an Alzheimer's disease patient with mutation in the APP gene. Stem Cell Res. 2022, 60, 102690. [CrossRef]

104. Li, X.; Meng, G.; Krawetz, R.; Liu, S.; Rancourt, D.E. The ROCK inhibitor Y-27632 enhances the survival rate of human embryonic stem cells following cryopreservation. Stem Cells Dev. 2008, 17, 1079-1085. [CrossRef]

105. Mollamohammadi, S.; Taei, A.; Pakzad, M.; Totonchi, M.; Seifinejad, A.; Masoudi, N.; Baharvand, H. A simple and efficient cryopreservation method for feeder-free dissociated human induced pluripotent stem cells and human embryonic stem cells. Hum. Reprod. 2009, 24, 2468-2476. [CrossRef] [PubMed]

106. Zhang, P.; Wu, X.; Hu, C.; Wang, P.; Li, X. Rho kinase inhibitor Y-27632 and Accutase dramatically increase mouse embryonic stem cell derivation. Vitr. Cell. Dev. Biol. Anim. 2012, 48, 30-36. [CrossRef]

107. Maldonado, M.; Luu, R.J.; Ramos, M.E.P.; Nam, J. ROCK inhibitor primes human induced pluripotent stem cells to selectively differentiate towards mesendodermal lineage via epithelial-mesenchymal transition-like modulation. Stem Cell Res. 2016, 17, 222-227. [CrossRef] [PubMed]

108. Effect of Y-27632 on CCE Colony Formation and Morphological Changes A...। Download Scientific Diagram. Available online: https:/ / www.researchgate.net/figure/Effect-of-Y-27632-on-CCE-colony-formation-and-morphological-changes-AB-Cells-in_fig9_41487781 (accessed on 10 February 2022).

109. Xu, Y.; Ding, W.; Li, S.; Li, C.; Gao, D.; Qiu, B. A single-cell identification and capture chip for automatically and rapidly determining hydraulic permeability of cells. Anal. Bioanal. Chem. 2020, 412, 4537-4548. [CrossRef] [PubMed]

110. Roffay, C.; Molinard, G.; Kim, K.; Urbanska, M.; Andrade, V.; Barbarasa, V.; Nowak, P.; Mercier, V.; García-Calvo, J.; Matile, S.; et al. Passive coupling of membrane tension and cell volume during active response of cells to osmosis. Proc. Natl. Acad. Sci. USA 2021, 118, e2103228118. [CrossRef]

111. DeJarnette, J.M.; Barnes, D.A.; Marshall, C.E. Effects of pre-and post-thaw thermal insults on viability characteristics of cryopreserved bovine semen. Theriogenology 2000, 53, 1225-1238. [CrossRef]

112. Correa, J.R.; Heersche, G.; Zavos, P.M. Sperm membrane functional integrity and response of frozen-thawed bovine spermatozoa during the hypoosmotic swelling test incubation at varying temperatures. Theriogenology 1997, 47, 715-721. [CrossRef]

113. Correa, J.R.; Zavos, P.M. Frozen-thawed bovine spermatozoa diluted by slow or rapid dilution method: Measurements on occurrence of osmotic shock and sperm viability. Theriogenology 1995, 44, 963-971. [CrossRef]

114. Correa, J.R.; Rodriguez, M.C.; Patterson, D.J.; Zavos, P.M. Thawing and processing of cryopreserved bovine spermatozoa at various temperatures and their effects on sperm viability, osmotic shock and sperm membrane functional integrity. Theriogenology 1996, 46, 413-420. [CrossRef]

115. Chen, C.X.Q.; Abdian, N.; Maussion, G.; Thomas, R.A.; Demirova, I.; Cai, E.; Tabatabaei, M.; Beitel, L.K.; Karamchandani, J.; Fon, E.A.; et al. A multistep workflow to evaluate newly generated ipscs and their ability to generate different cell types. Methods Protoc. 2021, 4, 50. [CrossRef]

116. Brenière-Letuffe, D.; Domke-Shibamiya, A.; Hansen, A.; Eschenhagen, T.; Fehse, B.; Riecken, K.; Stenzig, J. Clonal dynamics studied in cultured induced pluripotent stem cells reveal major growth imbalances within a few weeks. Stem Cell Res. Ther. 2018, 9, 165. [CrossRef] [PubMed] 